\title{
Is there any Relation of Normal Body Temperature with Stress
}

\section{Eating?}

\section{Qadir MI and Qureshi HN*}

Institute of Molecular Biology and Biotechnology, Bahauddin Zakariya University, Pakistan

*Corresponding author: Hira Naeem Qureshi, Institute of Molecular Biology and Biotechnology, Bahauddin Zakariya University, Multan, Pakistan, Email:

Research Article

Volume 2 Issue 1

Received Date: May 05, 2019

Published Date: May 16, 2019

DOI: $10.23880 /$ aabsc-16000123

hiranaeem2306@gmail.com

\section{Abstract}

The relation of normal body temperature with stress eating was aim of present research. 125 subjects took part in present research, where their normal body temperature measured. Thermometer is widely used to measure body temperature. The normal temperature of body is in between $36.5-37.5^{\circ} \mathrm{C}\left(97.7-99.5^{\circ} \mathrm{F}\right)$. The overeating during stress and tension is called stress tension. The unhealthy and junk foods are also connected with stress eating. The 125 students take part in this study. They measured their body temperature by thermometer and check that there is any relation of temperature with stress eating. This was resulted from current study that normal body temperature has no effect on stress eating.

Keywords: Temperature; Stress Eating; Thermometer

\section{Introduction}

The body temperature is define as the maintain balance of heat loss and heat gain by body. The normal temperature of body is in between $36.5-37.5^{\circ} \mathrm{C}(97.7-$ $99.5^{\circ} \mathrm{F}$ ). The body temperature is measured by various sites including vagina, ear, mouth, underarm, bladder, rectum and nose. Thermometer is widely used to measure body temperature. The maintenance of body temperature is called thermoregulation. The high body temperature is called hyperthermia. In this condition body absorbed greater heat then it released. The disturbed pulse rate, heavy sweating, vomiting, fainting, headaches, dizziness, rapid breathing and low blood pressure are symptoms of hyperthermia. The low body temperature is called hypothermia. In this condition body release more heat then it absorbed. The symptoms of hypothermia are mental confusion, paradoxical undressing, low sugar level and shivering [1].

The overeating during stress and tension is called stress tension. During stress adrenal gland received message from nervous system and cortisol hormone released that causing appetite and peoples eat more food. The stress eating is more common in females than males because during stress females eat food while males doing smoking. The unhealthy and junk food is also connected with stress eating. The overeating is major cause of the obesity that leads to serious and fetal diseases. The stress eating is minimized by reducing stress. The stress is 


\section{Annals of Advanced Biomedical Sciences}

reduced by exercise, mediation and social support [2]. Aim of the current study was to relate normal body temperature with stress eating.

\section{Materials and Methods}

The 125 subjects took part in current study. All subjects were students of Bahauddin Zakariya University, Multan, Pakistan. The body temperature is measured by thermometer. First we take a clean thermometer. Then placed the thermometer to under tongue. After few second remove thermometer and check the temperature.

\section{Statistical Analysis}

Statistical analysis was determined by $\mathrm{M}$ state. Student's $t$-test was used to check conclusion of $p$ value. The $p<0.05$ are considered as significant

\section{Result and Discussion}

The relation of normal body temperature with stress eating is given in Table 1 . The high body temperature is known as hyperthermia and hypothermia is called low body temperature. The 11 males with means 97.57 and standard deviation 0.77 are more addict of stress eating, 8 males with means 97.86 and standard deviation 1.26 are less addict of stress eating. Their $p$ value is 0.57 . The 54 females with means 96.73 and standard deviation 1.71 are more addict of stress eating, 52 females with means 96.75 and standard deviation 2.14 are less addict of stress eating. Their $p$ value is 0.96 . The 65 subjects with means 96.88 and standard deviation 1.62 are addict of stress eating, 60 subjects with means 96.90 and standard deviation 2.07 are less addict of stress eating. Their $p$ value is 0.94 . A questionnaire based studies have been given important outcome in current researches [3-10].

\begin{tabular}{|c|c|c|c|}
\hline Gender & People who addict of stress eating & People who don't addict of stress eating & $\boldsymbol{p}$ value \\
\hline Male & $97.57 \pm 0.77$ & $97.86 \pm 1.26$ & 0.57 \\
\hline Female & $96.73 \pm 1.71$ & $96.75 \pm 2.14$ & 0.96 \\
\hline Both & $96.88 \pm 1.62$ & $96.90 \pm 2.07$ & 0.94 \\
\hline
\end{tabular}

Table 1: Relation of Normal Body Temperature (Means \pm SD) with Stress Eating. Non-Significant $p>0.05$

\section{Conclusion}

This was resulted from current study that normal body temperature has no effect on stress eating.

\section{References}

1. Hammel HT, Pierce JB (1968) Regulation of internal body temperature. Annual review of physiology 30(1): 641-710.

2. Torres SJ, Nowson CA (2007) Relationship between stress, eating behavior, and obesity. Nutrition 23(1112): 887-894.

3. Qadir MI, Javid A (2018) Awareness about Crohn's Disease in biotechnology students. Glo Adv Res J Med Medical Sci 7(3): 062-064.

4. Qadir MI, Saleem A (2018) Awareness about ischemic heart disease in university biotechnology students. Glo Adv Res J Med Medical Sci 7(3): 059-061.
5. Qadir MI, Ishfaq S (2018) Awareness about hypertension in biology students. Int J Mod Pharma Res 7(2): 08-10.

6. Qadir MI, Mehwish (2018) Awareness about psoriasis disease. Int J Mod Pharma Res 7(2): 17-18.

7. Qadir MI, Shahzad R (2018) Awareness about obesity in postgraduate students of biotechnology. Int J Mod Pharma Res 7(2): 14-16.

8. Qadir MI, Rizvi M (2018) Awareness about thalassemia in post graduate students. MOJ Immunology 2(1): 14-16.

9. Qadir MI, Ghalia BA (2018) Awareness survey about colorectal cancer in students of M. Phil Biotechnology at Bahauddin Zakariya University, Multan, Pakistan. Nov Appro in Can Study 1(3): 1-5.

10. Qadir MI, Saba G (2018) Awareness about intestinal cancer in university student. Nov Appro in Can Study 1(3): 1-3. 